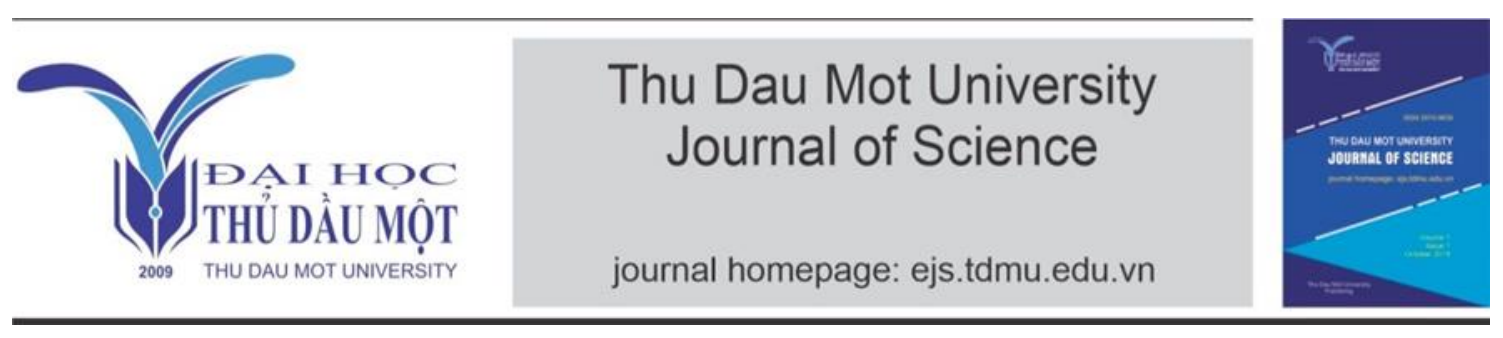

\title{
Accessibility to education services amongst mixed race children from Taiwanese-Vietnamese and Korean-Vietnamese marriages (Case study in Hau Giang province)
}

by Duong Hien Hanh (Thu Dau Mot University)

Article Info: $\quad$ Received 5April 2021, Accepted 2 Sep 2021, Available online 15 Sep 2021

Corresponding author: duonghh@tdmu.edu.vn

https://doi.org/10.37550/tdmu.EJS/2021.03.217

\begin{abstract}
To explain transnational marriage between Vietnamese brides and Taiwanese, Korean grooms. The author will figure out and discuss some issues related to this type of marriage such as divorce and one of concerning issues that VietnameseTaiwanese and Korean-Vietnamese children have been existing in Vietnam as 'being abandoned' phenomenon of transitional migration in the context of globalization. This research aims to gain an insight into accessibility to education services amongst Taiwanese-Vietnamese and Korean-Vietnamese children living with their mother and maternal family/relatives in Hau Giang by applying sociological approaches, thus to explain a modern social phenomenon emerging in the process of development and integration of Vietnam. Research subject: Accessibility to $s$ amongst Vietnamese-Taiwanese and Vietnamese-Korean children in Hau Giang. Research objects: Mixed race children nursed/care taken by their mother or maternal parents/relatives.
\end{abstract}

Keywords: Taiwanese-Vietnamese and Korean-Vietnamese children, transnational marriage, health care and education services

\section{Introduction}

Marriage involving foreign elements in this article is understood as marriage between Vietnamese woman and foreign man. Marriage with foreign factors is considered as a 
common and indispensable phenomenon in the context of globalization. Such marriage has had some consequences such as divorce. Marriage through brokers has led to the fact that both bride and groom relied on brokers. Dissatisfaction with one another when living together is one of causes of divorce. The bride was discriminated, abused and deported to Vietnam or she tried to escape with her child or has got a child after returning to Vietnam. The existence of Taiwanese-Vietnamese and Korean-Vietnamese children in Vietnam was mentioned in several reports at scientific conferences in recent years and considered as a social event that requires appropriate policies in response to the issues that children are facing, such as no birth certificates, difficult access to education and health care.

Education is one of crucially social institutions aiming to socialise individuals, to teach people how to grow up and integrate themselves into the community and society. The existence of mixed race children in Vietnam, particularly in this study in Hau Giang province is true. Opportunities for attending primary, secondary and high schools amongst Taiwanese-Vietnamese and Korean-Vietnamese children need to be considered on the basis of opportunity and equity as like other children living in the same area. Whether the justification for access to education is related to policy issues on education in Vietnam as well as the opportunity or accessibility to public education among migrant Taiwanese-Vietnamese and Korean-Vietnamese children remain some limitations due to legislations and policies on education or administrative procedures regarding to the status of children. Barriers of access to education among mixed race children need to be studied and analysed on the basis of scientific points of view that should be objectively studied and presented.

Social research approach would prove for the existence of vulnerable group of mixed race children, a social phenomenon established by the consequences of migration through transnational marriage since 1995s. New study findings would provide the education policy researchers with general information. The study would provide policy makers with evidence on neglected phenomenon in order to develop appropriate policies in response to the needs of modern society and towards to equality and justice in education.

\section{Concepts}

\section{Marriage involving with foreign elements}

On the basis of Article 826 in the Civil Code in 1995 regarding to civil relationship involving foreign elements, the notion of marriage and family relationship involving foreign elements were defined in the Law on Marriage and Family in 2000. According to Term 14 of Article 8 in Law on Marriage and Family in 2000, the marriage and 
family relationship involving foreign elements is stipulated as followed: 1) between a Vietnamese citizen and a foreigner, 2) both are foreigners permanently residing in Vietnam, 3) both Vietnamese who establish, change, terminate their relationship based on foreign Law or the properties related to their relationship in a foreign country. The concept used in this Paper is: Marriage involving foreign elements is the establishment of marital relationship in compliance with legal regulations in terms of marriage conditions and registration between a Vietnamese citizen and a foreigner.

\section{Taiwanese-Vietnamese and Korean-Vietnamese migrant children}

Immigrant children are the ones coming from another place and mentioned as mixed race children whose mother is Vietnamese and father is Taiwanese or Korean sent back to Vietnam living with their maternal relatives. It means that their maternal grandparents, biological mother or uncles, aunts take care of them in Vietnam.

\section{Accessibility to education}

Accessibility to education in this study is the possibility of Taiwanese-Vietnamese and Korean-Vietnamese attending school, studying like other children in the community. They are given with school record book, diploma and entitled to other benefits e.g. continuing higher education.

\section{Social inequality}

Social inequality is a status that members of the society possessing different quantity of assets, position or power. It is inequality in opportunities, rights and voice among individuals or group of people in social environment.

\section{Mixed race children}

Mixed race children in this study are children who were born by Vietnamese mother and Taiwanese or Korean father.

\section{Community children}

Community children are defined as children in Hau Giang province, holding Vietnamese nationality and their parents are Vietnamese.

\section{Approach}

Social research methodology was applied. Social phenomenon approach was used. Difference in access to education among two groups of children was analysed to justify the existence of Taiwanese-Vietnamese and Korean-Vietnamese children in Hau Giang province considered as a social phenomenon appeared post-reform stage, a consequence of transnational marriage among Taiwanese-Vietnamese and Korean-Vietnamese couples. 
There are 100 mixed race children and 100 community children in this research. Using quantitative method. The questioners were interviewed with the children's relatives. And there are 3 cases private interview with the authorities for more deep questions.

\section{Opinions on "social fact" by Durkheim}

According to Durkheim, Social facts become popular since they are social . Quantitative approach was used to compare and clarify the difference in health and education service user groups. Qualitative research tools were initially used to explore and justify a sensitive, social phenomenon (mixed race children) existing in Vietnam generally and in Hau Giang province particularly. According to Morse (1991), quantitative methodology would be more appropriate if studying a concept or phenomenon that none of studies have been conducted. Quantitative findings would be reviewed to select and develop tools for qualitative research that aimed to explore sensitive information and underlined causes behind a picture of Taiwanese-Vietnamese and Korean-Vietnamese children living with maternal grand-parents in Hau Giang, a province in the Mekong Delta, in which many women got married with Chinese/Taiwanese and Korean men. It was considered as a vulnerable group and representative group in the social science research.

\section{Institutional discrimination}

Discrimination and stigma do not only happen among individuals in their usual interactions but also institutions through daily activities. Institutional discrimination (Richard T.Schaefer, 2000) in this study aimed to explain for lack of opportunities to attend formal education or attain a diploma among Taiwanese-Vietnamese and KoreanVietnamese children in Hau Giang while community children (having Vietnamese nationality, Vietnamese parents) can. Educational institution of Vietnam is established through school attendance shown by school admission procedures, children's document, diploma or just for learning how to read and write, learning about Vietnamese culture. Discrimination is impossible to be verbally spoken out, but it can be interpreted by figures, and no hope to specifically show inequality in the topic. However, data analysis showed disparity in children when attending school (limitations in birth certificate, household book to be qualified for attending formal school and attaining diploma/certificate and school record book).

\section{Results}

\subsection{Taiwanese-Vietnamese and Korean-Vietnamese children's need for attending school}

Article 1 of Education Law provides for the national education system; schools, other educational institutions of the national education system, state agencies, political organizations, socio-political organizations, people's armed forces, organizations and 
individuals involved in educational activities. The goals of education are to train Vietnamese into comprehensively developed persons who possess moral qualities, knowledge, good health, aesthetic sense and profession, and are loyal to the ideology of national independence and socialism; to shape and foster personality, quality and capacity of citizens, satisfying the national construction and defence requirements

Apart from providing knowledge, skills, education aims to socialise people to ensure their employment, improve their living conditions. However, children's education needs are not fully met due to depending on the legal factors of the country. Despite the Vietnam's education is based on justice, there remain loopholes in kindergarten, primary and junior high education applied for Vietnamese citizens. Recently the presence of Taiwanese-Vietnamese and Korean-Vietnamese children in the community has created a rising issue on limited access to education among this children group. The facts showed that mixed race children sent back or born in the locality do not hold sufficient documents (notarised original copy of birth certificate) as required since their mother, father divorced, separated or mother secretly sent the child to be taken care by grand-parents (mother's parents) without her husband's consent. Therefore, it was hard to bring the child's birth certificate or to have the birth certificate sent back to Vietnam. In some cases, mother took her child to Vietnam and did not come back, so the child did not have birth certificate. Children's guardians and local leaders said that children need to go to school to learn literacy, to have opportunities or prevent risks while children are living in Vietnam until they turn 18 years old, become Vietnamese citizen, at least they are able to read and write.

According to regulations of school and education sector, all documents such as birth certificate, household book are required for school admission. In my point of view, we have to create conditions for children to go to school. You see if they live here and their parents broke up forever and they can have Vietnamese citizenship, it would be good for them. If they are not allowed to go to school, not educated at all, then they do not have any understanding...

IDI. Leader of Nang Mau Town

I think that children having birth certificate issued by the local government are considered as Vietnamese citizen. So it would be good if children can go to the school in Vietnam.... in general, every year we give priority to all children. None of children are left out. We mobilize 100\% of children to go to school.

IDI. Leader of Vi Thang Commune

In the interviews with the guardians/care-takers of Taiwanese-Vietnamese and KoreanVietnamese children, when being asked whether children's schooling in Vietnam was important or not, most of them (97\%) said that it was important while 3\% (3 respondents) said not.

TABLE 1: The responders for the importance of going to school 


\begin{tabular}{|c|c|c|}
\hline Go to the school is importance with children & 97 & $97 \%$ \\
\hline Go to the school is not importance with children & 3 & $3 \%$ \\
\hline
\end{tabular}

Source: Research data in 2016

Respondents reported that they tried to send their children to school, even finding the good quality school: my child attended Kim Dong School since I knew someone there. Otherwise, he/she would have gone to Vi Thuy 1 School. (IDI. Farmer- grand-father of Taiwanese child 3) Due to being aware of the importance of education, guardians/ caretakers, mothers really want their child to go to school as like others. When the child could not have a good study performance, the mother still asked the school to allow her child to study unofficially at the school: Now she was not in the list of pupils. I insisted the vice-Principle and she called just sending my child in the class so that she can learn as much as possible. (IDI. Farmer -mother of Korean child 1)

In 83 cases of children currently going to school, when being asked about the children's studying plan in Vietnam, $31.3 \%$ of respondents chose to follow it naturally and said that children would go to school till they cannot study. $31.3 \%$ answered that their children would go to school till whenever. However, some respondents gave specific plans such as completing college/university (accounting for 20.5\%), high school (6\%), secondary school (3.6\%) and primary school (7.2\%). It was easily found that respondents were unsure about the future of their children, did not have a specific option for their children. Quantitative research stopped at this point, though it was impossible to make a conclusion whether such points of view would affect children's education in the future or not. (Table 2)

TABLE 2: Plan for children go to school at Vietnam

\begin{tabular}{|l|l|l|}
\hline Plan & SL & \% \\
\hline Primary & 6 & 7.2 \\
\hline Secondary school & 3 & 3.6 \\
\hline High school & 5 & 6 \\
\hline University & 17 & 20.5 \\
\hline Study whenever children want & 26 & 31.3 \\
\hline Depending on the situation & 26 & 31.3 \\
\hline Total & $\mathbf{8 3}$ & $\mathbf{1 0 0}$ \\
\hline
\end{tabular}

Source: Research data in 2016

\section{Private tutor}


There was a difference between Taiwanese-Vietnamese and Korean-Vietnamese children group and community children group in primary, secondary and high school in terms of having private tutor. In 173 cases of children currently going to school, $83 \%$ of Taiwanese-Vietnamese and Korean-Vietnamese children remained going to primary, secondary and high school while community children accounted for $90 \%$.

\section{Compliment certificate}

Regarding to study performance, when being asked if children received compliment certificate last years, in 173 cases of children currently going to school, (74.7\%) 62 mixed race children (Taiwanese-Vietnamese and Korean-Vietnamese) reported of receiving certificate and $21(25.3 \%)$ children said not. In 88 cases of community children, $97.8 \%$ of respondents reported getting certificate and $2.2 \%$ said not. ChiSquare Test $(\mathrm{sig}=0.000<0.05)$ showed a significant difference in two groups of children attaining compliment certificate. The number of community children receiving compliment certificate was higher than mixed race children (Taiwanese-Vietnamese and Korean-Vietnamese). (Please see Table 3)

TABLE 3: Compare the difference of certificate between the mixed race children and community children

\begin{tabular}{|l|l|c|c|c|}
\hline \multicolumn{2}{|c|}{} & \multicolumn{2}{|c|}{ Children } & \multirow{2}{*}{ Sig } \\
\cline { 2 - 4 } \multicolumn{2}{|c|}{} & the mixed race children & community children & \multirow{2}{*}{0.000} \\
\hline \multirow{2}{*}{$\begin{array}{l}\text { Getting the } \\
\text { certificate from the } \\
\text { school }\end{array}$} & Yes & 62 & 88 & \\
\cline { 2 - 4 } & No & 19 & 2 & \\
\cline { 2 - 4 } & No respond & 1 & 90 & \\
\hline Total & 82 & 90 & \\
\hline
\end{tabular}

Source: Research data in 2016

Taiwanese-Vietnamese and Korean-Vietnamese children group has a disparity with community children group in terms of studying at the school, forms of schooling (official/ unofficial in the name list). It is so-called as 'informal schooling'. It was a difference between Taiwanese-Vietnamese and Korean-Vietnamese children and community children. $100 \%$ of community children and $81.9 \%$ of TaiwaneseVietnamese and Korean-Vietnamese children attended public school while $18.1 \%$ attended private school. This showed the difference in access to public education among two children groups. (Table 4)

TABLE 4: The difference in access to public education among two children groups

\begin{tabular}{|c|c|c|c|c|}
\hline \multirow{2}{*}{\multicolumn{2}{|c|}{ Kind of school }} & \multicolumn{2}{|c|}{ Children } & \multirow[b]{2}{*}{ Sig } \\
\hline & & Tthe mixed race children & community children & \\
\hline \multirow[t]{2}{*}{ Public school } & N0 & 78 & 90 & \multirow[t]{3}{*}{0.018} \\
\hline & $\%$ & $46.4 \%$ & $53.6 \%$ & \\
\hline Private school & N0 & 5 & 0 & \\
\hline
\end{tabular}




\begin{tabular}{|l|l|c|c|} 
& $\%$ & $100.0 \%$ & $0.0 \%$ \\
\hline \multirow{2}{*}{ Total } & N0 & 83 & 90 \\
\cline { 2 - 4 } & $\%$ & $48.0 \%$ & $52.0 \%$ \\
\hline
\end{tabular}

Source: Research data in 2016

The analysis above showed a disproportion in the average school age of TaiwaneseVietnamese and KoreanVietnamese children and community children in the study area. The average school age of TaiwaneseVietnamese and KoreanVietnamese children was one year higher than that of community children.

Regarding education, TaiwaneseVietnamese and KoreanVietnamese children had less access to public school than community children. This showed that mixed race children have a limitation in schooling. There was a disparity in two groups of children in terms of official schooling. Apparently $100 \%$ of community children were officially in the name list of school whereas $18 \%$ of mixed race children (TaiwaneseVietnamese and KoreanVietnamese) unofficially attended the school or out of the name list of class. In this situation, school children did not have mark records, not receive diploma like others.

\subsection{Policy barriers affecting children's study}

As stipulated by Vietnam Education Law, Vietnamese citizens are requested to submit birth certificate and household book in school application/enrolment. Children at school age must be sent to school. Especially the Government declared that universalisation of primary education has been accomplished. Foreign children are supposed to go to International school when they are living in Vietnam. As per regulations, children going to private or public school must have personal documents. The analysis emphasized on the participation status of TaiwaneseVietnamese and KoreanVietnamese children though public education was mainly available in Hau Giang province. Foreign children returning and residing in the community are considered as special group. Hence, differentiating the beneficiaries in Vietnam education policies is a challenge for TaiwaneseVietnamese and KoreanVietnamese children's access to education in the present context. Development of new education policies for TaiwaneseVietnamese and KoreanVietnamese children lacking personal documents e.g. birth certificate, Vietnamese household book is only a temporary solution to assist children to go to school. It means that TaiwaneseVietnamese and KoreanVietnamese children are qualified to go to school if not having sufficient some types of document such as birth certificate (original and translated copy) or Vietnam birth certificate or household book. However, children's schooling is only recognised (i.e. having school records) if the valid required documents of children are provided. Some options given by the local authorities are temporary. The local authorities can be flexible in approval for TaiwaneseVietnamese and KoreanVietnamese children to attend school. However, the 
issuance of diploma has to be in compliance with Education Law. This is justified by information from IDIs with local leaders. (Please see Box 2)

\section{Box 2}

I referred to school to approve for them to go to school. They also go through test and ranking but we can't give a diploma/certificate. They are allowed to go to school but we are not supposed to give them diploma. They need to study so that they can read and write, gain knowledge, understand about our Vietnamese traditions and culture.

IDI. Leader of Nang Mau Town

By doing this, we just can solve out 'the top of tree'. But it is not really the top of tree. So what to do when children go to high school in next one or two years? Where are their school records? There are many things required including household book. When students move to another school/ higher level, they have to submit birth certificate, household book, ID card etc.

IDI. Officer of Vi Thuy District Department of Justice

\section{Discussions}

Children having no birth certificate issued by the Government of Vietnam and those born in Vietnam by Vietnamese mother who remains marital relationship with Taiwanese or Korean husband are considered as foreign children, the issuance of Vietnamese birth certificate to children is not legal. As analysed above, the absence of household book or birth certificate in Vietnam has affected children's education. Children informally go to school without school testing records by the school in Vietnam. It showed that children' schooling was not certified and recognised since school records and diploma (important to prove for education of Vietnamese citizens) were not provided. The study has not figured out what effects/consequences? How it would affect children's life or their family and society? However, data analysis revealed an unusual social phenomenon that needs an in-depth study.

According to the respondents bringing up TaiwaneseVietnamese and KoreanVietnamese children, there was no difference in gender, age or education relevant to children's schooling as well as intentions, education plan for children. Qualitative research showed that respondents had no ideas about a specific education plan of their children and what level their children would reach. Majority of respondents said it was as far as possible. It is uncertainly a reason that children's education has not been carefully considered and prepared by their family before sending them back to Vietnam. Further studies are required to have an in-depth analysis on the roles of guardians/caretakers in TaiwaneseVietnamese and KoreanVietnamese children's access to education.

In conclusion, TaiwaneseVietnamese and KoreanVietnamese children's access to education in Hau Giang province was analysed on the basis of institution/policy discrimination and a social phenomenon approach by Durkheim. Study analysis 
revealed a rising social issue in the economic development process in the context of globalisation leading to migration through marriage easily. The number of TaiwaneseVietnamese and KoreanVietnamese children returning to their maternal family remains not small. A further in-depth study is needed to ensure children's entitlement to their fundamental benefits i.e. education.

\section{Note}

1. Principles of sociology approach - translated by Dinh Hong Phuc (2012)

\section{Reference}

Children with "foreign elements" cannot be born in Hau Giang: Where does education go? , Nguoi Lao Dong Newspaper, HCMC, accessed on September 16, 2014, at website http://laodong.com.vn/xahoi/trecoyeutonuocngoaikhongthelamkhaisinhohaugiangchuyen hochanhdivedau245239.bld.

Consular Department and Ministry of Foreign Affairs (2011). Migration Overview Report, Hanoi

Duong Hien Hanh (2015). Illegal marriage brokers and information asymmetry in transnational marriages China (China (Taiwan)) and Vietnam (bride case study) Vietnam returned to live locally. Journal of Family and Gender Studies 1, p. 2232

Emile Durkheim Rules of sociological methods Knowledge Publishing House, HCMC

Hoang Ba Thinh (2008). Public opinion on marriage with foreign elements, accessed on April 7, 2017, at website https://thongtinphapluatdansu.edu.vn/2008/06/12/d\%C6\%B0lu\%E1\%BA\%ADnxh\%E1\% BB\%99iv\%E1\%BB\%81hnnhncy\%E1\%BA\%BFut\%E1\%BB\%91n\%C6\%B0\%E1\%BB\% 9Bengoi/.

Ministry of Justice, Marriage and Family Law 2000, accessed June 4, 2017, at website http://moj.gov.vn/vbpq/Lists/Vn\%20bn\%20php\%20lut/View_Detail.aspx?ItemID=6123.

National Assembly (2015). Education Law, accessed on 07042017, at website http://www.moj.gov.vn/vbpq/lists/vn\%20bn\%20php\%20lut/view_detail.aspx?itemid=181 48. 